RELASI INJIL DAN KEBUDAYAAN: UPAYA MEMAKNAI LIFE-STORY GEREJA LOKAL

Raymundus Sudhiarsa, Ph.D., SVD

PEMBERDAYAAN SOSIAL EKONOMI SEBAGAI SUATU MODEL EVANGELISASI DALAM KONTEKS INDONESIA Dr. Ola Rongan Wilhelmus, SE, MS

MENUJU PENDIDIKAN KATOLIK YANG MEMIHAK ORANG MISKIN Agustinus W. Dewantara, SS

WAJAH BANGSA INDONESIA BARU : POTRET KUALITAS KELUARGA Antonius Tse, S. Ag

MENELADAN SIKAP PAUS YOHANES PAULUS II DALAM MENUMBUHKAN BUDAYA PERDAMAIAN

DI TENGAH KELUARGA Albertus I Ketut Deni Wijaya, S.Pd

LIMA CARA THOMAS AQUINAS MEMBUKTIKAN ADANYA TUHAN Hipolitus K. Kewuel, S.Ag, M. Hum.

Lembaga Penelitian

Sekolah Tinggi Keguruan dan Ilmu Pendidikan Teologi Katolik "Widya Yuwana"

MADIUN 


\section{JPAK \\ JURNAL PENDIDIKAN AGAMA KATOLIK}

Jurnal Pendidikan Agama Katolik (JPAK) adalah media komunikasi ilmiah yang dimaksudkan untuk mewadahi hasil penelitian, hasil studi, atau kajian ilmiah yang berkaitan dengan Pendidikan Agama Katolik sebagai salah satu bentuk sumbangan STKIP Widya Yuwana Madiun bagi pengembangan Pendidikan Agama Katolik pada umumnya.

\section{Penasehat}

Ketua Yayasan Widya Yuwana Madiun

\section{Pelindung}

Ketua STKIP Widya Yuwana Madiun

Penyelenggara

Lembaga Penelitian STKIP Widya Yuwana Madiun

\section{Ketua Penyunting}

Hipolitus Kristoforus Kewucl, S.Ag., M.Hum.

\section{Penyunting Pelaksana}

Hardi Aswinamo, MA, Pr

Drs. DB. Kaman Ardijanto, MA, Pr

Penyunting Ahli

Prof. Dr. Tondowidjojo, CM

Dr. Ola Rongan Wilhelmus, SF, MS

Dr. Armada Riyanto, CM

\section{Sekretaris}

Gabriel Sunyoto, S.Pd.

\section{Alamat Redaksi}

STKIP Widya Yuwana

Jn. Mayjend Panjaitan. Tromolpos: 13. Telp. 0351-463208. Fax. 0351-483554 Madiun 63102 - Jawa Timur - Indonesi3

Jurnal Pendidikan Agama Katolik (JPAK) diterbitkan oleh Lembaga Penelitian, STKIP Widya Yuwana Madiun. Terbit 2 kali setahun (April dan Oktober). Terbit Perdana April 2009. Pendiri: Hipolitus K. Kewuel. 


\section{JPAK}

Vol. 2, Tahun ke-1, Oktober 2009

ISSN; 2085-0743

\section{DAFTAR ISI}

02 Editorial

03 RELASI INJIL DAN KEBUDAYAAN: UPAYA MEMAKNAI LIFE-STORY GEREJA LOKAL

Raymundus Sudhiarsa, Ph.D., SVD

28 PEMBERDAYAAN SOSIAL EKONOMI SEBAGAI SUATU MODEL EVANGELISASI DALAM KONTEKS INDONESIA

Dr. Ola Rongan Wilhelmus, SF, MS

42 MENUJU PENDIDIKAN KATOLIK YANG MEMIHAK ORANG MISKIN

Agustinus Wisnu Dewantara, SS

55 WAJAH BANGSA INDONESIA BARU: POTRET KUALITAS KELUARGA

Antonius Tse, S. Ag.

67 MENELADANI SIKAP PAUS YOHANES PAULUS II DALAM MENUMBUHKAN BUDAYA PERDAMAIAN DI TENGAH KELUARGA

Albert I Ketut Deni Wijaya, S.Pd.

81 LIMA CARA THOMAS AQUINAS MEMBUKTIKAN ADANYATUHAN

Hipolitus K. Kewuel 


\title{
PEMBERDAYAAN SOSIAL EKONOMI SEBAGAI SUATU MODEL EVANGELISASI DALAM KONTEKS INDONESIA
}

\author{
Dr. Ola Rongan Wilhelmus, SF, MS \\ Sekolah Tinggi Keguruan dan Ilmu Pendidikan Agama Katolik \\ Widya Yuwana Madiun
}

\begin{abstract}
Upaya evangelisasi pada saat ini perlu diindentikan dengan upaya melawan arus besar zaman. Gelombang kapitalisme yang sedang menyusup masuk hampir ke semua bidang kehidupan dan imbasnya ialah semakin meningkatnya angka kemiskinan dan kemelaratan. Boleh dibilang, zaman ini adalah zamannya kapitalime dan masa suram kaum kecil, miskin, dan papa. Essensi keberadaan dan kehadiran agama-agama termasuk gereja katolik adalah memperjuangkan nasib dan hal hidup kaum miskin yang semakin bergantung pada kemurahan dan kebaikan kaum kapitalis. Tulisan ini memberi kontribusi khas bagaimana pemberdayaan sosial ekonomi masyarakat kecil menjadi bentuk hidup dan membebaskan mereka dari ketergantungan pada kaum kapitalis, elit politik dan pengusaha besar, evangelisasi yang berpihak kepada kaum miskin papa dengan maksud meningkatkan kesejahteraan hidup. Bagaimana mereka dituntun untuk berdaya dan menemukan sendiri apa yang mereka idam-idamkan tanpa harus bergantung kepada kaum kapitalis dan elit politik.
\end{abstract}

Key Words: Evangelisation, Capitalism, Social Economic Empowerment, Poverty

\section{Penduluan}

Masyarakat dan umat Katolik Indonesia terus berhadapan dengan permasalahan sosial-ekonomi yang tetap membingungkan. Ketika 
pemerintah terus mengucur dana ratusan miliar rupiah setiap tahun untuk pemberdayaan sosial-ekonomi dan pengetasan kemiskinan, jumlah masyarakat miskin tetap tidak mengalami penurunan. Di saat proyek pemberdayaan sosial-ekonomi semakin keras ditiup dan digembar-gembor, masyarakat bukanya mengalami pembebasan dan kesejahteraan sosialekonomi malainkan semakin bergantung kepada segelintir elit pengusaha, politisi dan investor asing. Persoalan ini menunjukkan realitas bahwa kesejahteraan dan keadilan sosial-ekonomi dalam hidup bersama sebagai suatu bangsa masih jauh dari harapan. Menghadapi kenyataan ini, kiranya salah satu tugas utama dari kita sebagai Gereja ialah mencermati atau menganalisis situasi sosial, politik, ekonomi dan budaya secara mendalam dan menyeluruh dalam rangka mencari suatu bentuk evangelisai sosialekonomi yang diharapkan dapat membawa pembebasan bagi masyarakat kecil atau membuat mereka bisa keluar dari belenggu kemiskinan dengan kekuatan sendiri.

Tulisan ini bermaksud melakukan suatu analisis singkat atas persoalan sosial-ekonomi khususnya kemiskinan yang dihadapi masyarakat dan bangsa kita; mengkeritisi persoalan ini dalam perspektif iman Kristen; dan melakukan diskusi tentang pemberdayaan sosial ekonomi sebagai suatu model evangelisasi yang dapat dikembangkan Gereja Katolik. Menjawabi tujuan penulisan ini maka, makalah ini secara berurut-turut akan melakukan diskusi tentang: 1) pemahaman dasar tentang ekonomi dan pemberdayaan sosial ekonomi; 2) masalah sosial-ekonomi dan kemiskinan Indonesia; 3) respons atas masalah sosial-ekonomi dan kemiskinan dalam terang Iman Kristian; dan 4) pemberdayaan sosial ekonomi sebagai sebuah model evangelisasi dalam Gereja.

\section{Ekonomi dan Pemberdayaan}

Istilah 'ekonomi' berasal dari bahasa Yunani yaitu "oikos" dan "nomos". Artinya 'tata kelola rumah tangga'. Tata-kelola itu diperlukan supaya kesejahteraan hidup rumah tangga bisa tercapai. Disini istilah 'ekonomi' merujuk pada proses atau usaha pengadaan barang dan jasa untuk kebutuhan hidup rumah tangga. Akan tetapi mengingat bahwa barang dan jasah yang diperlukan untuk hidup itu sangat terbatas, sementara kebutuhan hidup manusia sangat banyak dan beragam maka, istilah ekonomi juga mengandung arti "seni memilih secara bijak antara banyaknya kebutuhan di satu pihak dan terbatasnya sumberdaya (beli) dan sarana 
(tukar) di lain pihak". Dalam perkembangannya, "ckonomi" yang artinya tata kelola rumah tangga itu diperluas menjadi "tata kelola negara-bangsa". Pada konteks ini, ekonomi mengandung arti seni-mengelola sumberdaya yang dimiliki suatu negara demi terwujudnya kesejahteraan dan keadilan hidup bersama (KWI, 2006).

Pembangunan sosial-ekonomi keluarga dan negara terus saja menjadi konsern dan tugas utama dalam kehidupan setiap orang dan anggota masyarakat. Mengapa? Sebab setiap manusia hanya bisa menghayati kebebasannya secara penuh kalau memiliki landasan hidup sosial-ekonomi yang baik mengingat ekonomi merupakan titik tolak kemajuan pendidikan, kesehatan serta kelayakan hidup sebagai pribadi manusia. Pada titik ini, masyarakat miskin, lemah dan terpinggirkan perlu dibantu sehingga berkembang dan memiliki kehidupan sosial-ekonomi yang layak sebagai manusia. Bantuan itu dapat diberikan antara lain melalui kegiatan pemberdayaan sosial-ekonomi keluarga dan komunitas basis dengan sasaran kemandirian sosial-ekonomi keluarga atau komuntas basis (Morison, 2008; Hanh, 2001)

Apa itu pemberdayaan sosial-ekonomi? Pemberdayaan sosialekonomi ialah usaha memberi pengetahuan, keterampilan serta menumbuhkan kepercayaan diri serta kemauan kuat dalam diri seseorang sehingga mampu membangun suatu kehidupan sosial-ekonomi yang lebih baik dengan kekuatan sendiri. Singkatnya, pemberdayaan sosial-ekonomi bermaksud menciptakan manusia swadaya dalam kegiatan sosial-ekonomi. Pemberdayaan sosial-ekonomi ini pada intinya dapat diupayakan melalui berbagai kegiatan antara lain pelatihan, pendampingan, penyuluhan, pendidikan dan keterlibatan berorganisasi demi menumbuhkan dan memperkuat motivasi hidup dan usaha, serta pengembangan pengetahuan dan keterapilan hidup dan kerja. Pemberdayaan ini perlu dilakukan atas keyakinan dasar bahwa setiap orang termasuk orang yang paling miskin sekalipun mampumengubah hidupnya dengan kekuatan sendiri. Keyakinan ini perlu terus ditumbuh-kembangkan dan menjadi kultur hidup seharihari. Cita-cita pemberdayaan ialah "berdiri di atas kaki sendiri" (Blackburn, 2005; Morison, 2008; Freire, 1995).

Tantangan terbesar terhadap pemberdayaan sosial-ekonomi ialah masyarakat kecil terlalu sering dibuat bergantung kepada sistem pemerintahan, birokrasi, institusi politik dan ekonomi yang otoriter dan feodalistik yang dimainkan para pengusaha besar dan internasional corperation yang 
erat bekerjasama dengan para politisi nasional dan lokal. Hal ini mengakibatkan pembangunan sosial-ekonomi berbasis kemandirian masyarakat kecil di tanah air saat ini kurang berkembang. Sebaliknya ketergantungan masyarakat kepada para pengusaha, pemilik modal dan pemerintah semakin besar. Faktor lain yang menghambat permbangunan sosial-ekonomi yang berbasis kemandirian ialah terus membengkaknya utang luar negeri. Kwik Gian Gie (2009) bernendapat bahwa utang luar negeri tidak menguntungkan perputaran roda kemandirian ekonomi rakyat sebab memperlemah investasi masyarakat serta menghancurkan manajemen ekonomi nasional dan lokal yang berorientasi pada kemandirian sosial-ckonomi rakyat.

Menghadapi tantangan ini, perlu dibangun suatu etos kemandirian berpikir, mengambil keputusan serta bertindak atas dasar kesadaran dan pertimbangan pribadi dalam diri masyarakat. Hal ini selaras dengan apa yang dikatakan Abdul Rahman Wahid (2004) bahwa kualitas masyarakat mandiri periu ditingkatkan schingga lebih mampumengatasi persoalan hidup sehari-hari, memiliki daya tawar terhadap pemerintah, pasar dan dunia perdagangan internasional yang terus menguasai situasi pasar dan industri ditanah air.

\section{Potret Kehidupan Sesial-Ekonomi}

Di tengah kelimpahan sumberdaya alam, kita terus menyaksikan bahwa masih ada sekian banyak warga masyarakat Indonesia yang masih sangat miskin dan memprihatinkan. Data statistik Indonesia (2009) menunjukan bahwa 39.05 juta atau $17.5 \%$ dari total masyarakat Indonesia hidup dalam keadaan sangat miskin karena hanya mampuh mempertahankan hidupnya dengan total biaya hidup sekitar Rp 5128 / hari. Kalau kita menggunakan standar hidup Rp 15.000/hari/orang maka jumlah warga masyarakat miskin di Indonesia meningkat drastis menjadi 110 juta atau $49 \%$ dari total penduduk Indonesia saat ini (World Bank, 2009; BPSN, 2009). Di Jawa Timur, hasil survey sosial-ekonomi Nasional Badan Pusat Statistik Jatim (2008) mengatakan bahwa jumlah penduduk yang terkatagori sangat miskin di Jawa Timur tercatat sekitar 7,456 juta jiwa atau $18.93 \%$ dari jumlah total penduduk propinsi ini. Angka kemiskinan ini lebih tinggi dibandingkan dengan angka kemiskinan tahun 2007 yaitu 7, 138 juta jiwa.

Menghadapi kenyataan ini, banyak upaya telah dilakukan baik oleh pihak pemerintah dan swasta untuk mengatasi persoalan kemiskinan. 
Meskipun demikian, upaya yang dilakukan itu belum menunjukkan kemajuan yang berarti hingga saat ini. Mengapa? Karena pemerintah dan partner bisnis papan atas terus mempromosikan investasi dan usaha bersekala besar yang terus didominasi oleh pemilik modal besar dan asing. Sementara itu usaha-usaha ekonomi bersekala kecil atau mikro menyangkut hanyat majoritas masyarakat Indonesia justeru kurang mendapat perhatian (KWI, 2006; Ola Rongan, 2009).

Saat ini aset-aset masyarakat dan negara terus dikuasai pengusaha besar dan International corporations. Sumberdaya produktif masyarakat kecil seperti lahan basah dan kering serta hutan terus mengalami penciutan dari tahun ke tahun. Sumberdaya ekonomi rakyat kecil ini begitu mudah berubah menjadi pusat-pusat perbelanjaan besar dengan kehadiran mall dimana-mana. Situasi ini tercipta karena dukungan kebijakan ekonomi nasional yang cendrung berpihak kepada usaha-usaha bersekala besar dan investor asing. Kebijakan ekonomi ini berakibat buruk bagi kebanyakan masyarakat kelas menegah ke bawah. Sebab kebijakan ini bukannya mengurangi angka kemiskinan tetapi menciptakan ketergantungan luar biasa dari masyarakat kecil dan menengah ke bawah kepada segelintir orang yang menguasai kegiatan ekonomi bersekala besar. Dari tahun ke tahun, daya serap dari usaha-usaha berskala besar atas tenaga kerja yang tidak profesional terus menurun. Akibatnya jumlah lapangan kerja menurun dan jumlah penganggur pada sektor kelas menengah ke bawah terus meningkat.

Ketika penggangguran dan kemiskinan meningkat maka, jumlah anak yang putus sekolah pasti bertambah. Sementara itu, kejahatan dan kekerasan sosial meningkat, gizi buruk bertambah. Dampak kemiskinan dan pengangguran ini lebih sering dialami oleh segmen masyarakat paling lemah, khusnya anak-anak dan para ibu. Tahun 2007, jumlah bayi yang lahir dengan kondisi berat badan di bawah normal karena kurang gizi, mencapai 350.000 . Sementara itu bayi di bawah lima tahun (balita) yang menderita busung lapar berjumlah 1,67 juta. Jumlah ini meningkat menjadi 2,4 juta pada tahun 2008 . Jumlah kematian ibu yang melahirkan adalah 307 per 100.000 kelahiran pada tahun 2007 . Ini berarti, dalam setiap1 jam terdapat 2 ibu di Indonesia meninggal ketika sedang bersalin (BPSN, 2008).

Wajah kemiskinan ini hadir berdampingan dengan penumpukan kekayaan oleh sekelompok kecil masyarakat Indonesia. Mereka terus 
hidup dalam suasana kelimpahan. Situasi ini sebetulnya memberikan suatu potret nyata bahwa bangsa kita telah kehilangan kepedulian pada cita-cita kesejahteraan bersama. Pertanyaannya ialah apa kiranya yang menyebabkan kesuraman ekonomi serta kemiskinan ini? Analisis sosial dan ekonomi telah menemukan sejumlah faktor penyebab. Diantaranya ialah penerapan mekanisme pasar secara brutal, kebijakan publik yang tidak berpihak kepada masyarakat kecil, globalisasi dan kesenjangan budaya.

Saat ini tengah berlangsung kecenderungan kuat untuk menerapkan mekanisme pasar ke semua bidang kehidupan. Mekanisme pasar memegang teguh prinsip "hak hidup seseorang atas barang/jasa ditentukan oleh daya-beli". Konsekuensi dari prinsip ini ialah semakin seseorang mempunyai uang, semakin dianggap lebih "berhak" atas barang/jasa tertentu. Sebaliknya, semakin seseorang tidak mempunyai uang, semakin ia dianggap "tidak berhak" termasuk hak atas kebutuhan hidup yang paling mendasar seperti makanan, pendidikan dan kesehatan (KWI. 2006; KWI. 2008).

Kita tentunya sependapat bahwa perdagangan (pertukaran) perlu diciptakan karena mempermudah perolehan barang dan jasah demi pemenuhan kebutuhan hidup. Akan tetapi mekanisme pasar ini tidak bisa diterapkan dalam semua hal. Sebab banyak kebutuhan dasar menyangkut kelangsumgan hidup bersama seperti makanan, pendidikan dan kesehatan (obat-obatan) seharusnya tetap dijaga sebagai milik bersama. Penerapan mekanisme pasar secara membabi buta ke semua bidang kehidupan tidak akan membantupencapaian kesejahteraan hidup bersama serta menyangkal hak asasi dari ratusan juta masyarakat Indonesia atas kebutuhan hidup pokok terutama makanan, pendidikan dan jaminan kesehatan. Kalapun masyarakat kecil mengalami kesejahteraan ditengah penerapan mekanisme pasar seperti ini maka, kesejahteraan yang dialami itu tidak lebih dari sekedar hasil "tetesan ke bawah" dari segelintir orang kaya yang berkelebihan. Praktek kehidupan sosial-ekonomi seperti ini tentunya menciptakan ketergantungan dan kemiskinan dan bukanya pembebasan. Disni ekonomi yang berbasis pasar tidak lagi terkait dengan cita-cita kesejahteraan bersama dan melawan hak asasi hidup manusia (Morison, 2008; KWI, 2006).

Di tengah kehidupan mekanisme pasar yang merugikan masyarakat ini, pemerintah seharusnya menjaga dan memastikan bahwa kesejahteraan bersama tetap menjadi tujuan utama hidup berbangsa yang diperjuangkan 
melalui berbagai kebijakan publik. Kebijakan publik merupakan perangkat utama pemerintah untuk mengejar tujuan dan kesejahteraan bersama. Akan tetapi keyataan hidup menumjukan bahwa banyak oknum pemerintah lebih suka memanfaatkan posisi jabatan serta kebijakan publik untuk memperkaya diri. Tidak sedikit kalangan legislatif, eksekutif, maupun yudikatif terus mengingkari mandat yang diterimanya dari masyarakat untuk memperjuangkan kesejahteraan bersama. Mereka lebih mengutamakan perjuangan kenainkan gaji dan tunjangan hidup pribadi dari pada kepentingan dan kemajuan masyarakat yang diwakili.

Kondisi sosio-ekonomi yang suram saat ini sering juga dikaitakan dengan proses globalisasi. Globalisasi memang memunculkan harapan baru karena memberi atau menawarkan banyak kebaikan dan kemudahan. Sebagai contoh, akses terhadap kemudahan informasi, ilmu pengetahuan dan teknologi saat ini menjadi sangat mudah karena proses globalisasi serta perkembangan teknologi komunikasi yang luar biasa. Di sisi lain globalisasi juga memberi kemudahan luar biasa kepada para pengusaha besar dan dunia international corporations untuk menetukan dan mengendalikan harga jual-beli pasar sesuai dengan pertimbangan profit sendiri. Akibatnya, kaum miskin yang memiliki daya beli rendah sering menjadi korban mekanisme harga-jual beli pasar. Hidup dan mati masyarakat kecil seperti petani, nelayan, buruh pabrik dan perusahan menjadi semakin bergantung pada kebaikan dan kemurahan hati dari mereka yang menguasai mekanisme ekonomi pasar (Narayaan, 2002; Morison, 2008). Di sini mekanisme pasar global telah menjadi sebuah imperalisme semu.

Observasi dan analisa sosial menunjukan bahwa saat ini masyarakat kita telah mengalami sebuah kesenjangan budaya. Hal ini bisa terlihat dari munculnya suatu kebiasaan hidup dan pola berpikir serta tindak yang tidak lagi sesuai dengan apa yang dibutuhkan. Misalkan saja, bertumbuhnya sikap dan kebiasaan menghamburkan sumberdaya ekonomi untuk keperluan pesta dan rekreasi; korupsi waktu, uang, jabatan; serta minum mabuk sampai mati. Keadaan ini diperparah dengan cara berpikir dan memandang bahwa"ckonomi pasar" menupakan sumber segala kemajuan. Cara pikir ini membuat prinsip kesejahteraan bersama lalu dianggap sebagai hasil sampingan dari pengejaran kepentingan pribadi/individual. Kemudian kesejahteraan masyarakat kecil merupakan hasil belas kasihan dari mereka yang kaya dan berkelimpahan. 


\section{Meneropong Realitas Sosial-Ekonomi Dalam Terang Iman Kristen}

Gereja yakin bahwa dimensi moral dari kehidupam sosial-ekonomi terletak pada visi Gereja tentang martabat manusia sebagai ciptaan Allah dan karena itu kudus. Sebagai ciptaan Mlahi, Allah hadir dalam diri setiap orang. Tidak ada dimensi kehidupan manusia yang luput dari perhatian dan cinta Allah. Karena itu martabat pribadi manusia merupakan tolok ukur untuk berbagai program, kegiatan dan kebijakan pengembangan dan pemberdayaan sosial-ekonomi. Martabat manusia tidak bisa menjadi alat yang bisa dieksploitasi untuk tujuan-tujuan sempit seperti mendapatkan kekayaan, kedudukan dan jabatan sosial sesaat. Ketika institusi atau tatanan sosia-ekonomi gagal mrespons martabat manusia dan sebaliknya memperparah kemiskinan maka, tatanan sosial-ekonomi seperti penerapan mekanisme pasar secara brutal perlu dipertanyakan secara serius dan ditransformasi (Curan. 2002; Gutierrez, 1983; KWI, 2006).

Kitab Suci selalu mengingatkan kita akan rencana dan kerinduan Allah atas diri manusia. Allah menghendaki supaya setiap manusia saling menghormati dan menghargai. Penghargaan ini dapat ditunjukan melalui cara hidup yang dijiwai semangat kekeluargaan dan keadilan termasuk keadilan sosia-ekonomi. Sikap adil ini ditunjukan pertama-tama kepada kelompok masyarakat kecil, miskin dan termarginalisasi. Sikap adil ini perlu juga diperlihatkan dalam kegiatan pembangunan dan pemberdayaan sosial-ekonomi yang berpihak kepada kepentingan masyarakat kecil dan miskin. Dalam iman Kristiani, keberpihakan ini tidak lain merupakan wujud konkrit partisipasi aktif manusia dalam karya penciptaan Ilahi dengan maksud membangun suatu bentuk kehidupan bersama yang layak dan adil (Gutierrez, 1983; The Bishop Conference of the United States. 2009).

Realitas sosial-ekonomi sering menunjukan bahwa kekayaan alam dan lingkungan yang tersedia untuk semua orang telah dimonopoli dan rusak karena keserakahan segelintir orang yang terus mengejar keuntungan pribadi. Kerakusan ini merupakan akar dari berbagai bentuk kemiskinan material dan moral yang membelenggu sekian banyak orang saat ini. Meskipun demikian, banyak elit politik dan bisnis sampai saat ini tetap saja melihat kaum miskin sebagai penyebab utama kemiskinan karena kebodohan dan kemalasan sendiri. Ketika menuding terus masyarakat kecil sebagai sumber kemiskinan maka, mata banyak orang tidak akan bisa 
melihat lagi bahwa kerakusan, kurangnya kemampuan pemimpin bangsa mengelola potensi kekayaan masyarakat secara adil, elit politik yang terlalu mengedepankan kepentingan pribadi, serta korupsi sebagai penyebab struktural dari persoalan kemiskinan (Ola Rongan, 2009).

Ketika dunia dilanda kemiskinan, ketidakadilan sosial serta kerakusan manusia, Putera Allah datang menebarkan kasih Ilahi kepada semua orang, terutama kepada yang miskin dan lemah. Dengan menjadi manusia, Yesus Putera Allah berbicara dan menjanjikan pembebasan bagi "kaum tawanan" dan "penglihatan bagi orang buta". Pada saat tampil pertama kali di depan umum, Yesus memaklumkan: "RohAllah ada diatas diriku, karena Allah mengurapi aku untuk memaklukan kabar gembira kepada kaum miskin" (Lk 18; Yes 61: 1-2). Dalam Injil Lukas, Yesus menunjukan keberpihakannya kepada orang miskin dengan mengecam orang kaya: "tetapi celakalah kamu yang kaya sebab dengan kekayaanmu kamu telahmemperoleh penghiburan" (Lk 6:24) (Gutierrez, 1983; Michacl Mattci, 2003; Curan, 2002).

Karya cinta kasih dan pembebasan Yesus itu memberi pesan bahwa orang kaya dan berkuasa perlu mawas diri agar tidak terbelenggu oleh sikap cinta diri yang sempit dan buta terhadap kepentingan sesama. Yesus menasehati para muridNya supaya melawan ketamakan dan sikap yang menggantungkan diri secara berlebihan pada kekayaan material dan kuasa duniawi. Yesusmempertegas hal ini melalui perumpamaan tentang hidup seorang laki-laki yang langsung lenyap ketika sedang bersusah payah mengumpulkan kekayaan (Lk 12: 13-21). Pada sisi lain, pembebasan Yesus membuat kaum miskin dan lemah tidak boleh pasrah, putus asah dan tenggelam di dalam ketidakberdayaan. Masyarakat kecil dan lemah tidak boleh buta terhadap berbagai peluang untuk membangun hidup menjadi lebih baik dan manusiawi. Sebaliknya karya pembebasan Yesus harus menjadi sumber inspirasi dan kekuatan mengubah kondisi kehidupan sosial-ekonomi menjadi lebih baik. Yesus tidak menolak kekayaan. Hal ini terlihat dari sikap Yesus yang memuji hamba yang menggandakan talentanya, tetapi mengecam hamba yang malas dan tidak menggandakan talenta. Alasan Yesus tidak menolak kekayaan ialah karena kelayakan hidup dan martabat manusia sebagai ciptaan Allah diukur juga menurut pemenuhan kebutuhan sosial-ekonomi. (Gutierrez, 1983; Michael Mattei. 2003). 


\section{Pemberdayaan Sosial-Ekonomi Sebagai Sebuah Model Evangelisasi}

Setelah membaca realitas sosial-ekonomi dan merefleksikannya dalam terang iman kristiani maka, langkah berikutnya ialah mencari dan menawarkan suatu model evangelisasi (pewartaan) yang memungkinkan masyarakat bisa mengalamai suatu kehidupan yang lebih baik tidak hanya secara spiritual tetapi juga secara material (sosial-ekonomi). Disini akan kita diskusikan "Pemberdayaan Sosial-Ekonomi" sebagai suatu model evangelisasi dengan sasaran peningkatan kualitas serta pemenuhan kebutuhan rohani dan jasmani (sosial-ekonomi) masyarakat kecil dan miskin (Michael Mattei, 2003; The Bishop Conference of the United States. 2009).

Pilihan atas pemberdayaan sosial-ekonomi sebagai sebuah model evangelisasi ini terletak pada panggilan dan misi Gereja mewartakan harapan akan kebaikan, kemajuan, kesejahteraan dan keadilan hidup bersama. Harapan tentang kebaikan bersama ini mempunyai dasar kuat dalam janji Allah: "Ia yang memulai pekerjaan yang baik di antara kamu, akan meneruskannya sampai pada hari Kristus Yesus" datang. Janji Allah ini mengandung arti bahwa Allah tetap giat dan aktif memanggil dan membimbing setiap orang untuk mengambil bahagian dalam aktivitas Ilahi yaitu membangun dan memanfaatkan dunia demi kehidupan yang lebih baik, layak dan membebaskan. Kitab Kejadian serta Kebijaksanaan secara jelas mengatakan bahwa manusia diciptakan Allah untuk menghasilkan buah, menguasai dan sekalihgus memimpin, merawat dan mengarahkan dunia ini sesuai dengan kehendak Mlahi (Kejadian 2: 15; 1:28; Kebijaksanaan 9:3).

Tugas dan tanggungjawab mengolah dan membangun dunia ini memerlukan kesanggupan, pengetahuan dan keterampilan khusus. Merspons kebutuhan akan kesanggupan, pengetahuan dan keterampilan ini, Gereja perlu memiliki kepekaan dan komitmen yang kuat untuk mendorong kerjasama antara elemen pemerintah, kekuatan pasar dan komunitas basis guna melakukan bersama kegiatan "pemberdayaan sosialekonomi" masyarakat, terutama masyarakat kecil dan terpinggirkan. Dimaksudkan dengan pemberdayaan sosial-ekonomi ialah usaha memberi motivasi, dorongan, pengetahuan dan keterampilan kepada masyarakat agar mampuh mengolah dan memanfaatkan potensi dan energi ekonomi mereka sendiri secara kreatif dan berkelanjutan seturut kehendak Ilahi. 
Pemberdayaan ini diharapkan dapat menggerakan potensi masyarakat untuk membangun kesejahteraan sosial-ekonomi dengan kekuatan sendiri serta membebaskan mereka dari ketergantungan hidup kepada kekuatan ekonomi makro (berskala besar) serta belas kasihan pemerintah dan segelintir orang kaya (Ola Rongan, 2009; KWI, 2006).

Pemberdayaan sosial-ekonomi sesungguhnya terjadi secara konkrit ketika Gereja mulai melakukan pendidikan serta pengadaan modal secara mandiri untuk pemberdayaan. Hal ini bisa dilakukan melalui pendidikan dan pembentukan sikap enterpreneurship, suka menabung, hidup hemat dan jujur serta ulet dan disiplin dalam kerja. Pemberdayaan sosial-ekonomi juga terjadi ketika Gereja mulai terlibat aktif mendidik dan mendorong umat basis untuk memperjuangkan dan melindungi bersama lingkungan hidup sendiri termasuk lahan produktif; mengorganisir pengaturan sampah secara sehat dan produktif; mengupayakan tersedianya informasi bagi masyarakat kecil tentang peluang usaha, bantuan finansial, produksi, pasar; dan kerjasama dengan berbagai instansi lain demi kemajuan dan kesejahteraan hidup bersama (Konpernas XXI PSE KWI. 2008; KWI, 2000).

Pemberdayaan sosial-ekonomi tentunya ini perlu didukung oleh sebuah pola hidup spiritualitas yang lebih menekankan nilai kemerdekaan, kebebasan dan pertobatan, Bukanya pola spiritualitas yang menekankan nilai pragmatis, individualistik atau sibuk dengan diri sendiri. Singkatnya, pemberdayaan memerlukan dukungan sikap pertobatan hidup yang bisa dihayati melalui beberapa cara sebagai berikut:

Pertama, membangun tekad dalam diri masyarakat kecil/miskin supaya berani mengubah hidup dengan kekuatan sendiri tanpa bergantung pada inisiatif atau kekuatan luar seperti pemilik modal dan pemerintah. Tekad ini berakar pada keyakinan dasar bahwa setiap orang termasuk masyarakat yang paling miskin dan lemah sekalipun memiliki enegri atau potensi mengubah hidup dengan kekuatan sendiri.

Kedua, mendesak para pembuat dan pelaksana kebijakan publik supaya menghentikan kecenderungan menjual-beli jabatan dan posisi yang diperoleh dari rakyat demi keuntungan sendiri. Sebaliknya mendorong upaya membuat dan merealisir kebijakan publik yang bermuara pada proses pemberdayaan, kemandirian, serta kesejahteraan dan keadilan sosialekonomi.

Ketiga, menggalang dan mendorong para cerdik-pandai supaya lebih terbuka dan aktif melakukan kajian kritis tentang ide/gagasan serta cara- 
cara berpikir tentang pembangunan dan pemberdayaan sosial-ckonomi yang terlalu dipolitisir dan merugikan masyarakat miskin dan lemah. Kajian kritis itu diharapkan pula dapat melahirkan ide/gagasan, cara berpikir serta tindakan baru dengan menempatkan pemberdayaan sosial-ekonomi masyarakat kecil sebagai prioritas (KWI, 2000; KWI, 2006).

\section{Penutup}

Indonesia dilimpahi dengan kekayaan sumber alam secara luar biasa. Meskipun demikian, kita terus menyaksikan sekian banyak warga kita tetap hidup miskin. Karena itu kemiskinan tetap saja merupakan suatu masalah besar bagi bangsa kita saat ini.

Berbagai usaha telah dilakukan pihak pemerintah dan swasta untuk mengatasi kemiskinan. Tetapi upaya itu belum menunjukkan kemajuan yang berarti karena terhadang oleh sejumlah faktor seperti penerapan mekanisme pasar secara brutal, kebijakan publik yang tidak berpihak pada masyarakat kecil, globalisasi dan lain-lain.

Melihat realitas kemiskinan ini, Gereja terpanggil untuk melibatkan diri secara aktif dalam proses pemberdayaan sosial-ekonomi masyarakat dengan visi membangun manusia swadaya. Manusia swadaya ialah manusia yang mampu berpikir, merencanakan dan mewujudkan mimpi, harapan dan cita-cita hidup kedepan dengan usaha dan kekuatan sendiri.

Pemberdayaan sosial-ekonomi perlu didukung oleh sikap pertobatan sejati dalam arti pembaharuan tekad dan keberanian melepaskan diri dari kebergantungan pada pemilik modal besar dan pemerintah; menciptakan kebijakan publik yang mendorong tercapainya kemandirian sosial-ekonomi rakyat; serta menumbuhkan kesadaran akan panggilan intelektual dan nurani untuk menawarkan cara berpikir dan bertindak yang lebih kreatif dan inovatif demi perubahan hidup yang lebih baik. 


\section{SUMBER BACAAN}

Blackbum. 2005. Understanding of Paolo Freire: Reflection on the Origins, Concept dan Possible Pitsfalls of his Educational Approach. Community Development Journal. Vol. 35. No.1.

Charles, E. Curan. 2002. Catholic Social Teaching,1891-Present.

Dreier, P. 2002. Community Empowerment Strategy: The Limits and Potential of Community Organizing in Urban Neighborhoods. Urban Affairs Quarterly 26(2). New Jersey, USA.

Freire, P. 1995. Pedagogy of Hope: Receiving Pedagogy of the Oppressed. Continuum Standford Press, New York, USA.

Gustavo Gutierrez. 1983. The Power of the Poor in History. Orbis Book. Maryknoll, New York,

Hanh, H. 2001. Alternatif Views of Empowerment: Social Services and Civil Rights. Joumal of Rehabilitations, 54 (4). California, USA

KWI. 2006. Habitus Baru: Ekonomi Yang Berkeadilan-Keadilan Bagi Semua. Dalam Nota Pastoral KWI.

KWI. 2000. Memberdayakan Komunitas Basis Menuju Indonesia Baru. Sidang Agung Gereja Katolik Indonesia. Wisama Kanasih, Bogor, Jawa Barat

Michael Mattei (Ed), 2003. Option for the Poor. The Wesley Center for Applied Theology. Northwest Nazarene University. USA

Morison C. 2008. Health, Education and Poverty Reduction. OECD Publication. New York, USA

Narayan, D. 2002. Empowerment and Poverty Reduction. The International Bank of Reconstruction and Development of the World Bank, Washington, DC, USA

Konpernas XXI PSE KWI. 2008. Lampung Road Map: Kerasulan Sosial Ekonomi 
Gereja Katolik Indonesia. Bandar Lampung.

Ola Rongan Wilhelmus.2009. Pemberdayaan Masyarakat di Tengah Proses Marginalisasi Sosial. Buletin Yabisa. No.2/November

Ola Rongan Wilhelmus. 2008. Social Construction of Poverty and People Empowerment Among Members of Selected Basic Christian Community in the Philippines. Disertasi.

The Bishop Conference of the United States. 2009. The Christian Vision of Economic Life Mary Knoll, New York. 


\section{PERSYARATAN PENULISAN ILMIAH DI JURNAL JPAK WIDYA YUWANA MADIUN}

01. Jumal IImiah JPAK Widya Yuwana memuat hasil-hasil Penelitian, Hasil Refleksi, atau Hasil Kajian Kritis tentang Pendidikan Agama Katolik yang belum pernah dimuat atau dipublikasikan di Majalah/Jurnal IImiah lainnya.

02. Artikel ditulis dalam Bahasa Indonesia atau Inggris sepanjang 7500-10.000 kata dilengkapi dengan Abstrak sepanjang 50-70 kata dan 3-5 kata kunci.

03. Artikel Hasil Refleksi atau Kajian Kritis memuat: Judul Tulisan, Nama Penulis, Instansi tempat bernaung Penulis, Abstrak (Indonesia/Inggris), Kata-kata Kunci, Pendahuluan (tanpa anak judul), Isi (subjudul-subjudul sesuaikebutuhan), Penutup (kesimpulan dan saran), Daftar Pustaka.

04. Artikel Hasil Penelitian memuat: Judul Penelitian, Nama Penulis, Instansi tempat bernaung Penulis, Abstrak (Indonesia/lnggris), Kata-kata Kunci, Latar Belakang Penelitian, Tinjauan Pustaka, Metode Penelitian, Hasil Penelitian, Penutup (kesimpulan dan saran), Daftar Pustaka

05. Catatan-catatan berupa referensi disajikan dalam model catatan lambung.

Contoh: Menurut Caputo, makna religius kehidupan harus berpangkal pada pergulatan diri yang terus menerus dengan ketidakpastian yang radikal yang disuguhkan oleh masa depan absolut (Caputo, 2001: 15)

06. Kutipan lebih dari empat baris diketik dengan spasi tunggal dan diberi baris baru.

Contoh: Religions claim that they know man an the world as these really are, yet they they differ in their views of reality. Question therefore arises as to how the claims to truth by various religions are related. Are they complementary? Do they contradict or overlap one another? What -according to the religious traditions themselves-is the nature of religious knowledge?(Vroom, 1989: 13)

07. Kutipan kurang dari empat baris ditulis sebagai sambungan kalimat dan dimasukkan dalam teks dengan memakai tanda petik.

Contoh: Dalam kedalaman mistiknya, Agustinus pernah mengatakan "saya tidak tahu apakah yang saya percayai itu adalah Tuhan atau bukan." (Agustinus, 1997: 195)

08. Daftar Pustaka diurutkan secara alfabetis dan hanya memuat literature yang dirujuk dalam artikel. Contoh;

Tylor, E. B., 1903. Primitive Culture: Researches Into the Development of Mythology, Philosophy, Religion, Language, Ert, and Custom, John Murray: London

Aswinarno, Hardi, 2008. "Theology of Liberation As a Constitute of Consciousness," dalam Jurnal RELIGIONo. I, April 2008, hal. 25-35.

Borgelt, C., 2003. Finding Association Rules with the Apriori Algorthm, http://www.fuzzi.cs.uni-magdeburg.de/-borgeltlaprioril. Juni 20, 2007

Derivaties Research Unicorporated. http//fbox.vt.edu.10021/business/finance/ dmc/RU/content.html.Accesed May 13, 2003 


\section{Google}

\section{Cendekia}

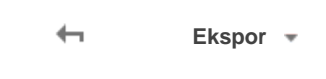

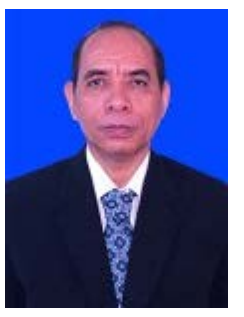

Ola Rongan Wilhelmus

\section{PEMBERDAYAAN SOSIAL EKONOMI SEBAGAI SUATU MODEL EVANGELISASI DALAM KONTEKS INDONESIA}

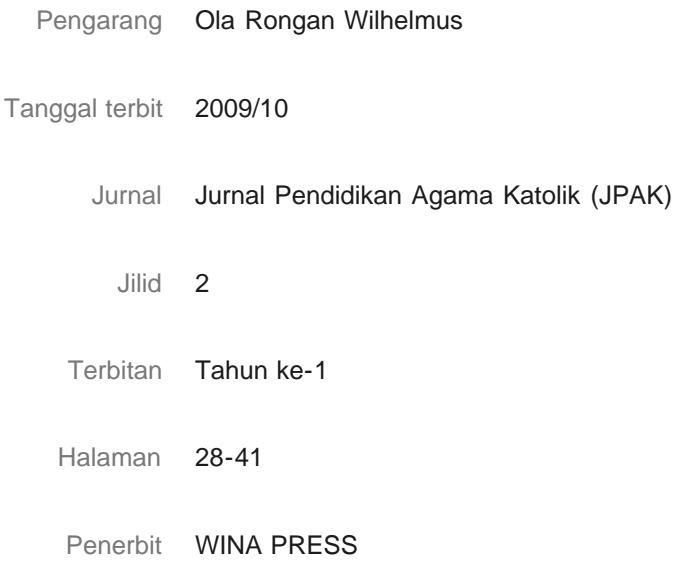

